\title{
ON THE MECHANISM OF IMPAIRMENT OF RENAL CONCENTRATING ABILITY IN POTASSIUM DEFICIENCY*
}

\author{
By ANDRZEJ MANITIUS, $\dagger$ HOWARD LEVITIN, $\ddagger$ DAVID BECK§ AND \\ FRANKLIN H. EPSTEIN \| \\ (From the Department of Internal Medicine, Yale University School of Medicine, \\ New Haven, Conn.)
}

(Submitted for publication October 14, 1959; accepted December 17, 1959)

A decrease in the ability of the kidneys to excrete a highly concentrated urine is one of the earliest hallmarks of potassium depletion in animals and in humans (1). According to present views of the mechanism of the renal concentrating process (2), this might be the result of $a$ ) impairment of the countercurrent multiplier system by which a high concentration of sodium (and urea) is created and maintained in the interstitial space of the renal papilla, and/or $b$ ) decreased permeability of the walls of the collecting ducts and distal tubules to the back-diffusion of water. If the first alternative were correct, analysis of the renal papilla from potassium-deficient animals excreting a maximally concentrated urine should reveal a lower concentration of sodium than that present in the papilla of normal animals. Should the second mechanism be operative, the fall in maximum urinary osmolality observed in potassium deficiency might be entirely unassociated with a decrease in papillary sodium, or else would be out of proportion to it.

In the present experiments samples of maximally concentrated urine and renal papilla, medulla and cortex from potassium-depleted rats and dogs were analyzed. By placing all animals on a sodium-free diet prior to sacrifice, difficulties in the interpretation of tissue analyses consequent to high concentrations of sodium in the urine were avoided. The results indicate that the

* Aided by grants from the American Heart Association, the National Heart Institute, the Lawrence $M$. Gelb Foundation, and a contract (MD-116) with the Office of the Surgeon General, Department of the Army.

† Special Fellow of the Rockefeller Foundation. Present address: Second Medical Service, Medical Academy, Gdansk, Poland.

$\ddagger$ Advanced Fellow of the American Heart Association.

$\S$ Fellow of the Dazian Foundation.

\| Established Investigator, American Heart Association. concentration of sodium and total solutes in the renal papilla is indeed decreased by potassium depletion, though the decrease is not as great as the fall in maximum urinary osmolality.

\section{Rats}

White male Sprague-Dawley rats initially weighing 150 to $200 \mathrm{~g}$ were divided into the following groups. The composition of the diets is given in Table $\mathrm{I}$.

Group IE. Twenty-four animals were fed a low potassium diet for 29 days, followed by 5 days of a low sodium, low potassium diet before sacrifice.

Group IC. Twenty-two rats received a normal diet for 23 days, followed by 5 days of a low sodium diet.

Group IIE. Twenty-eight rats received a high sodium, low potassium diet for 6 days. Desoxycorticosterone acetate (DCA), $0.2 \mathrm{mg}$ per rat, was injected subcutaneously daily for 5 days. Following this, a low sodium, low potassium diet was given for 9 days.

Group IIC. Twenty-four animals received a high sodium diet for 6 days and a low sodium diet for 5 days. In order to obtain enough papillary tissue for accurate analysis, 3 or 4 animals were kept in a cage and analyses of urine, plasma and tissue were performed on pooled material.

Twenty-four hours before sacrifice food and water were withheld. Twelve hours later $50 \mathrm{mU}$ of vasopressin in oil was injected subcutaneously and micturition was induced. The rats were then placed in metabolism cages with screens so placed as to deflect feces, and urine was collected under oil for 12 hours. Although precautions were taken to prevent evaporation, some (estimated from separate experiments as under 15 per cent) undoubtedly occurred as the urine passed over the screen and into the funnels. Rats were then removed from their cages, anesthetized with sodium pentobarbital, and the abdominal cavity was opened. Five $\mathrm{ml}$ of blood was aspirated anaerobically from the abdominal aorta and immediately thereafter both kidneys and about $4 \mathrm{~g}$ of thigh muscle were removed. Separate experiments established that the concentration of sodium in the renal papilla was not appreciably affected by preliminary bleeding in the manner described. The kidneys were sectioned longitudinally and slightly off center so that free access to the entire papilla was obtained (Figure 1A). The papilla was removed approximately at the point in- 
TABLE I

Composition of diets

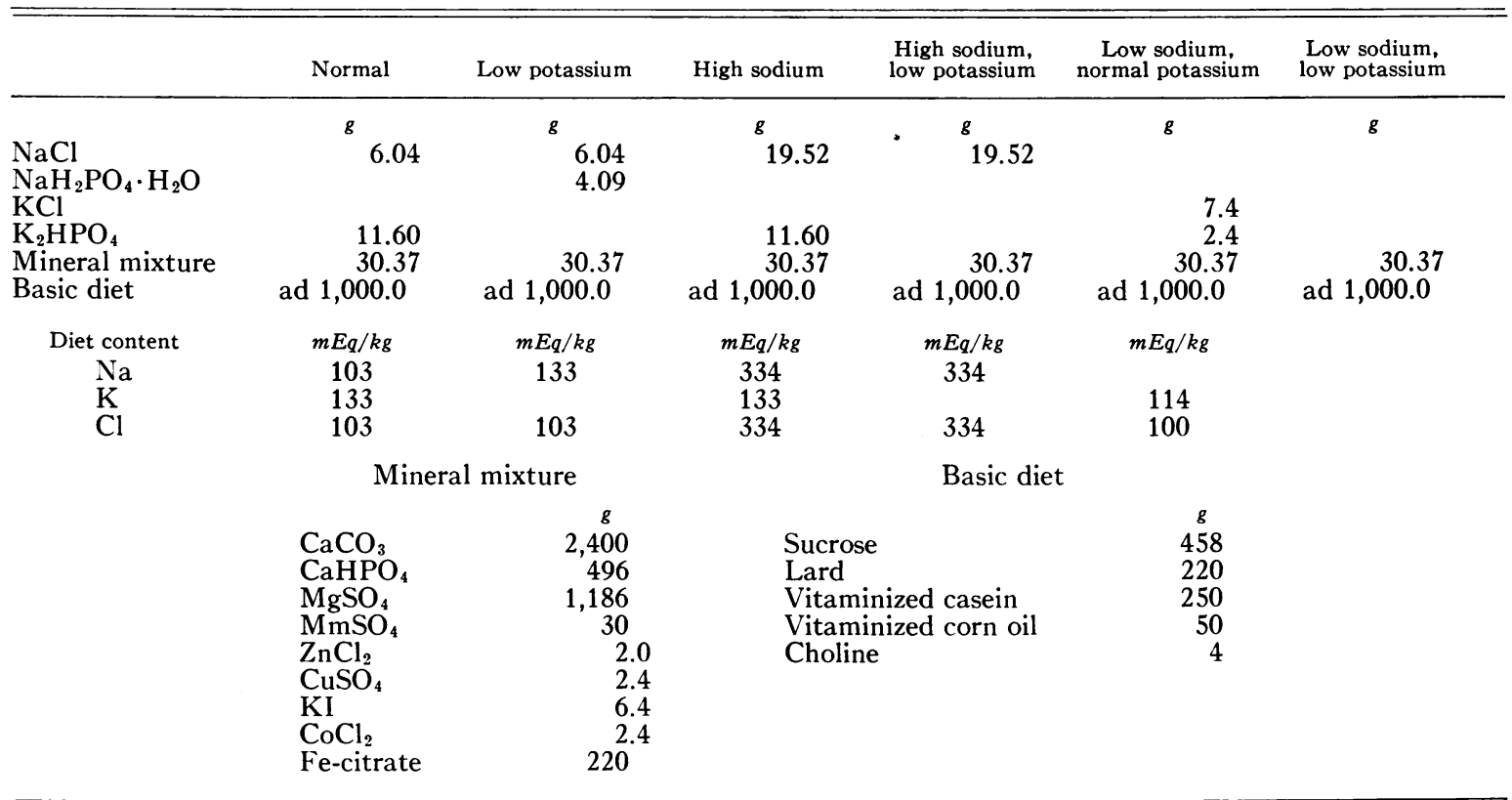

dicated in Figure IB. Portions of the inner medulla and cortex were then obtained.

\section{Dogs}

Five female mongrel dogs weighing 7 to $15 \mathrm{~kg}$, were depleted of potassium by a high sodium, low potassium diet (Table I) plus $1.0 \mathrm{mg}$ of DCA per $\mathrm{kg}$ of body weight injected subcutaneously each day for 7 to 9 days, followed by a low sodium, low potassium diet for 8 more days. A sixth animal received $45 \mathrm{~g}$ of potassium-exchange resin (Kayexalate, Winthrop) in its low potassium diet each day for 13 days, and was then placed on a low sodium, low potassium diet for 8 more days. Six other dogs served as controls and were fed for 4 to 8 days on the high sodium diet and then for 8 or 9 days with the low sodium diet. Water was withheld for 36 hours before sacrifice. Twelve hours and 2 hours before sacrifice, 5 units of vasopressin in oil was injected subcutaneously. A sample of venous blood was collected anaerobically and the dog was lightly anesthetized with sodium pentobarbital. (The anesthetic dose of pentobarbital is considerably reduced in potassium-depleted animals.) The bladder was emptied, washed with air, and urine was collected via an inlying catheter for the next 15 to 30 minutes. The abdomen was then opened and both kidneys were removed and sectioned transversely. Samples of papilla tip (20 to $60 \mathrm{mg}$ ), inner medulla ( 300 to $400 \mathrm{mg}$ ) and cortex (about $1,500 \mathrm{mg}$ ) were immediately removed and placed in weighing bottles.

\section{Analytical procedures}

In the rat experiments, tissue from one kidney was analyzed for urea and ammonia; tissue from the other kidney, for water and electrolytes. In the experiments on dogs, samples of each renal papilla, medulla and cortex were divided into two approximately equal portions. The portion for urea and ammonia analysis was placed in a weighing bottle containing clean dry sand. After weighing, the tissue and sand were transferred to a mortar and thoroughly ground. The mixture was suspended in a measured amount of water, transferred to a closed test tube and immersed in boiling water for 5 minutes. After cooling, the fluid was filtered and analyzed for urea and ammonia (3). The second portion of renal tissue was weighed, then desiccated for 5 days at $95^{\circ} \mathrm{C}$ and reweighed. Water content was determined after grinding, drying for another 24 hours at $95^{\circ} \mathrm{C}$ and weighing again. The ground dry tissue was then digested for 24 hours in concentrated nitric acid at $70^{\circ} \mathrm{C}$. Sodium and potassium were determined by indirect flame photometry on the filtered, diluted digest.

Muscle tissue was dried, extracted three times with anhydrous ether, ground, and digested with nitric acid before determination of sodium and potassium with a flame photometer.

Osmolality of urine and plasma was measured with the Fiske osmometer. Urine was diluted to an osmolality less than $1,000 \mathrm{mOsm}$ per $\mathrm{kg}$ prior to the determination of freezing point. $\mathrm{CO}_{2}$ content of plasma was measured with the van Slyke apparatus or the Natelson microgasometer. "Total solute" concentration in tissue was calculated as the sum of $2 \times\left(\mathrm{Na}+\mathrm{K}+\mathrm{NH}_{4}\right)$ t urea, where $\mathrm{Na}, \mathrm{K}, \mathrm{NH}_{4}$ and urea are expressed as millimoles per kilogram of tissue water. It must be emphasized that for many reasons (4) this value is at best 

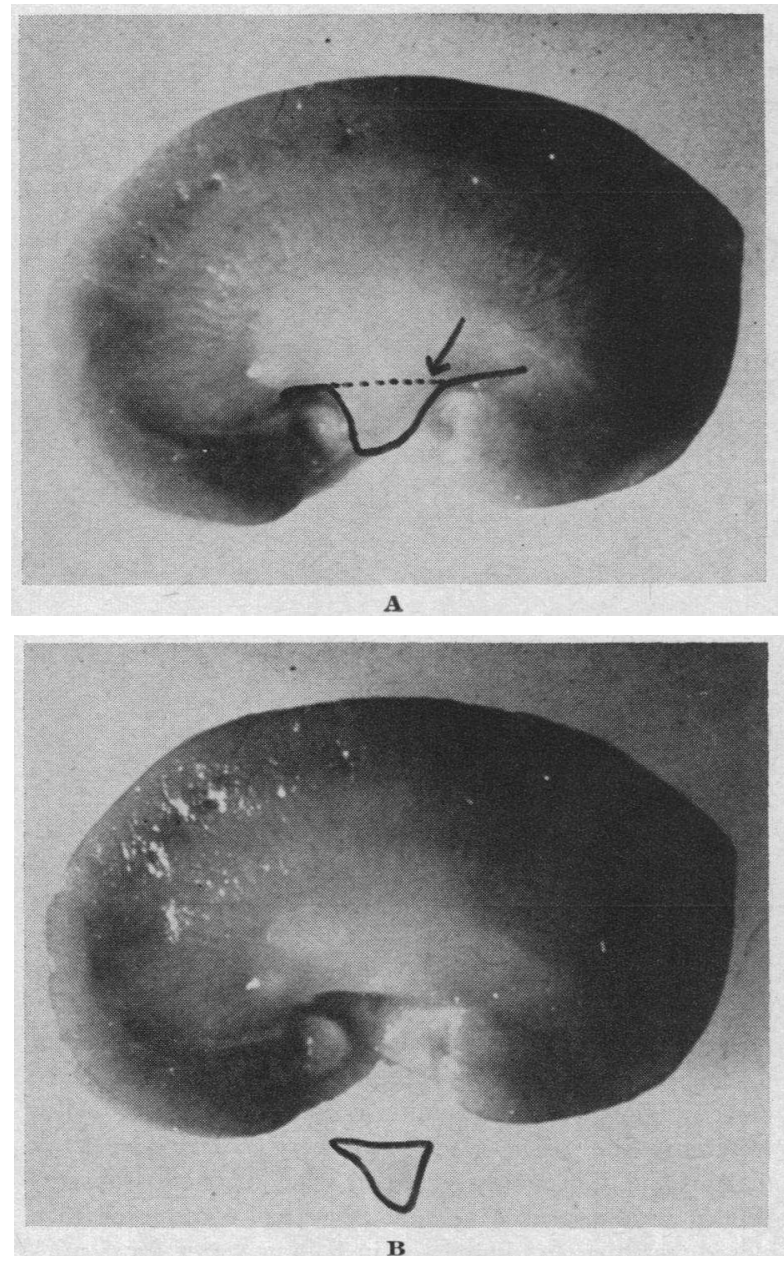

Fig. 1. A. RAT KIDNEY SECTIONED LONGitudinally. The arrow indicates the approximate point at which the papilla tip was excised. B. RAT KIDNEY AFTER EXCISION oF PAPILLA.

only a rough approximation of the osmotic activity of water in tissue.

\section{RESULTS}

I. Rats (Tables II and III). As reported many times by others $(5,6)$, potassium depletion produced by dietary means alone (Group IE) and by DCA (Group IIE) was associated with decreased weight gain, polyuria, renal hypertrophy, hypokalemia, alkalosis, a decrease in muscle potassium and an increase in muscle sodium (Table II). The potassium content of the papilla and cortex of depleted rats was lower than that of controls (Table III) but this was not true for the renal medulla.

On a sodium-free diet, potassium-depleted rats

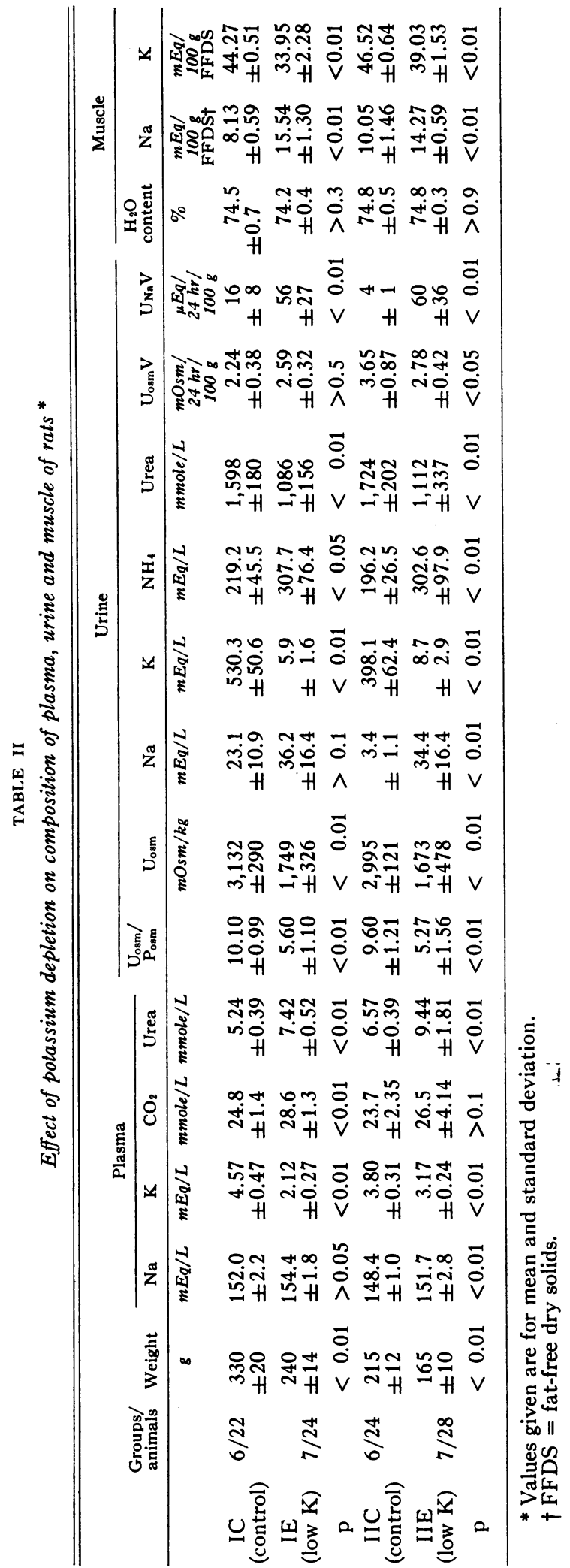




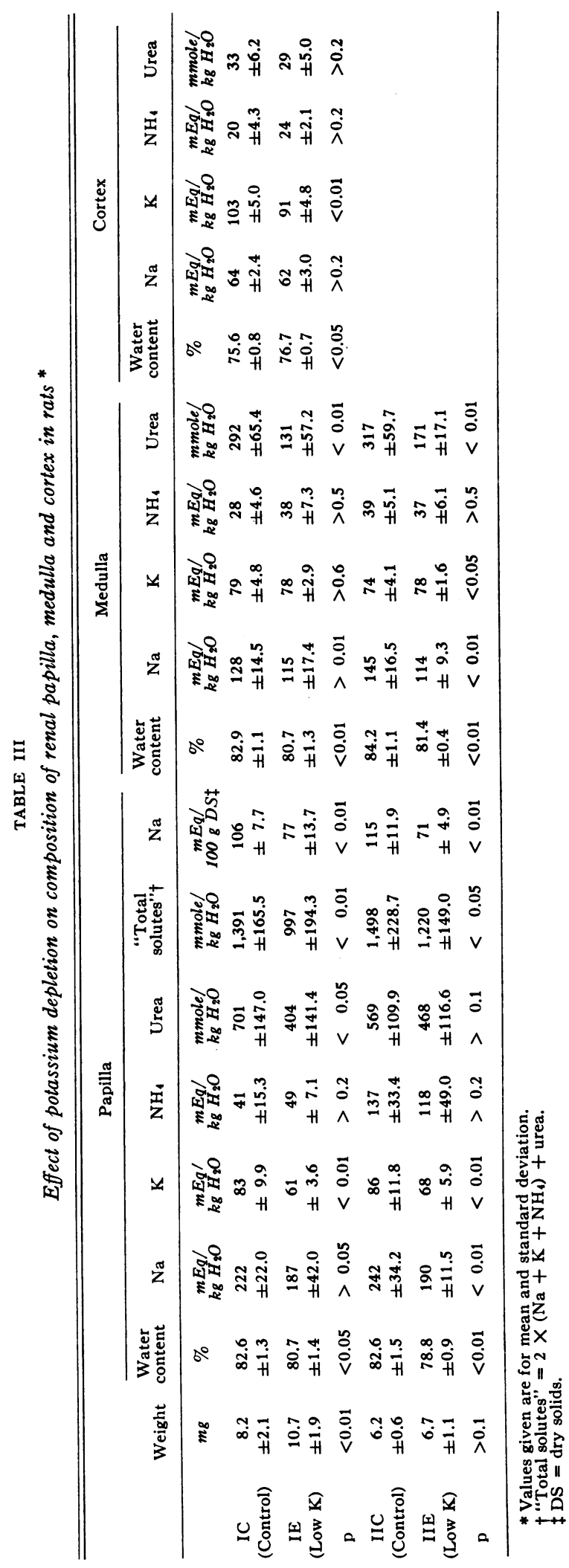

excreted more sodium in the urine than did normal controls deprived of sodium for a similar or shorter period (Table II).

The concentration of sodium and urea in renal tissue of normal rats increased progressively from cortex to papilla (Table III), as was reported by Ullrich and Jarausch in dogs (7). No such gradient was observed for potassium. The concentration of sodium in water of papillary tissue was considerably higher than that in peripheral plasma, even though the sodium concentration of urine was extremely low. "Total solute" concentration of papillary tissue was about one-half the osmolality of urine, but tended to increase as the sample excised for analysis became smaller and smaller as the tip of the papilla was approached, (Figure 2). The concentration of potassium in the urine of normal rats on a sodium-free diet was so high ( 400 to $500 \mathrm{mEq}$ per $\mathrm{L}$ ) when compared with the concentration of potassium in the renal papilla (70 to $90 \mathrm{mEq}$ per $\mathrm{kg} \mathrm{H}_{2} \mathrm{O}$ ) that urine could not possibly have made up more than 15 to 20 per cent of the water of the papilla, and probably was a good deal less than that.

Maximum urinary osmolality was approximately halved by potassium depletion. This was associated in both groups of depleted rats with a significant reduction in the amount of sodium per $100 \mathrm{~g}$ of dry solids of renal papilla. In group IE, the decrease in concentration of sodium, expressed as milliequivalents per kilogram of tissue

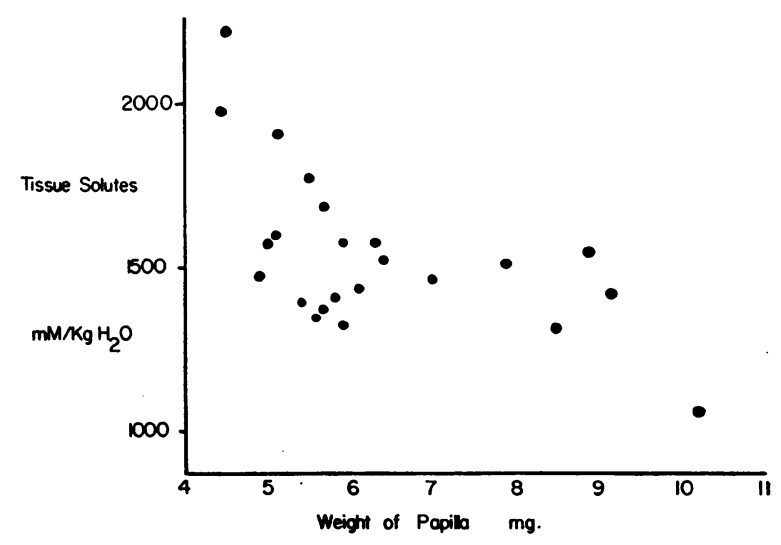

Fig. 2. Concentration of "Tissue solutes" $[2 \times$ $\left(\mathrm{NA}+\mathrm{K}+\mathrm{NH}_{4}\right)+$ UREA] IS PLOTTED VERSUS WEIGHT of ANALYZED SAMPLE of PAPILLA. As the tip of the papilla is approached (i.e., as the sample analyzed becomes smaller) the concentration of solutes in tissue water rises. 

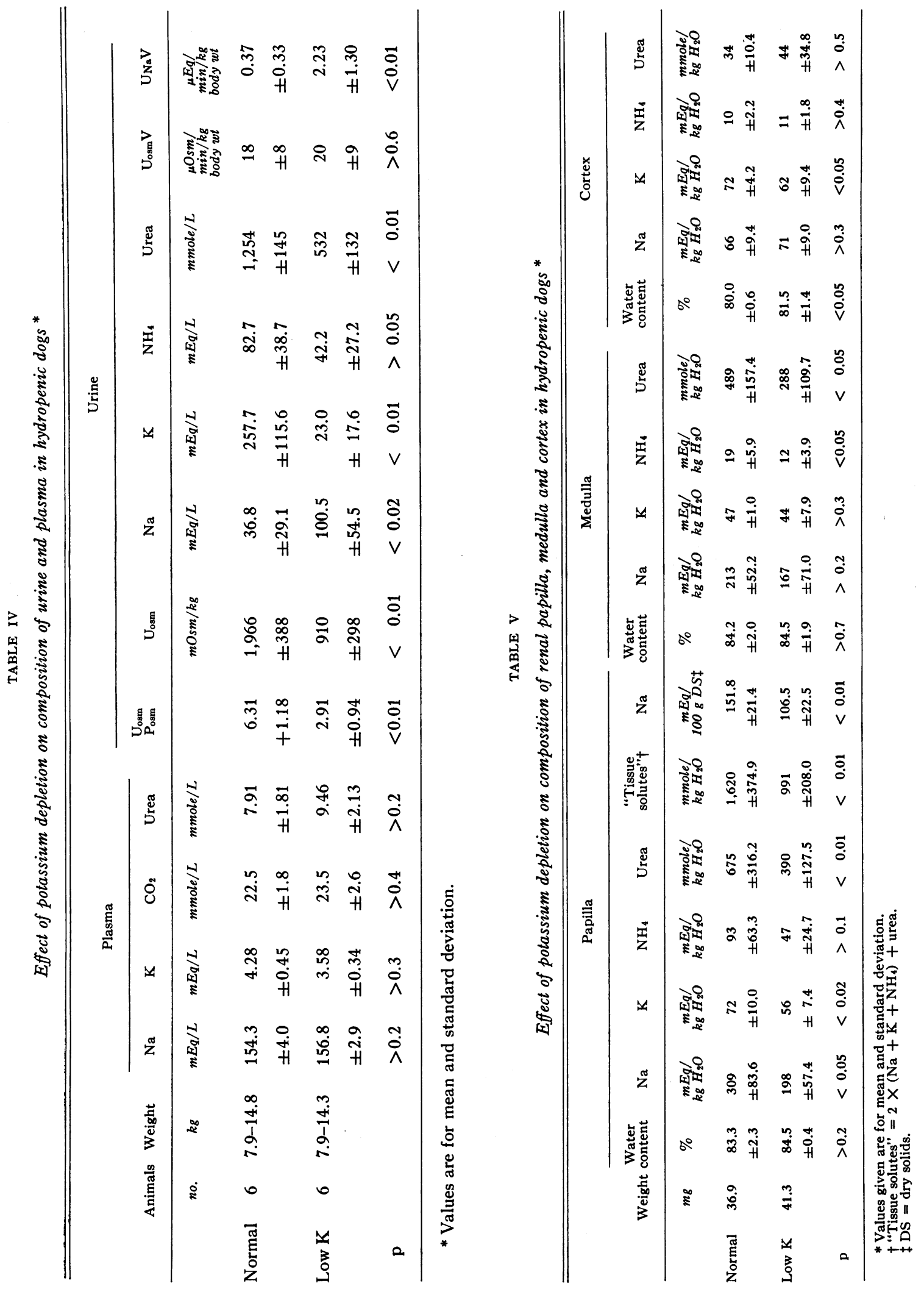


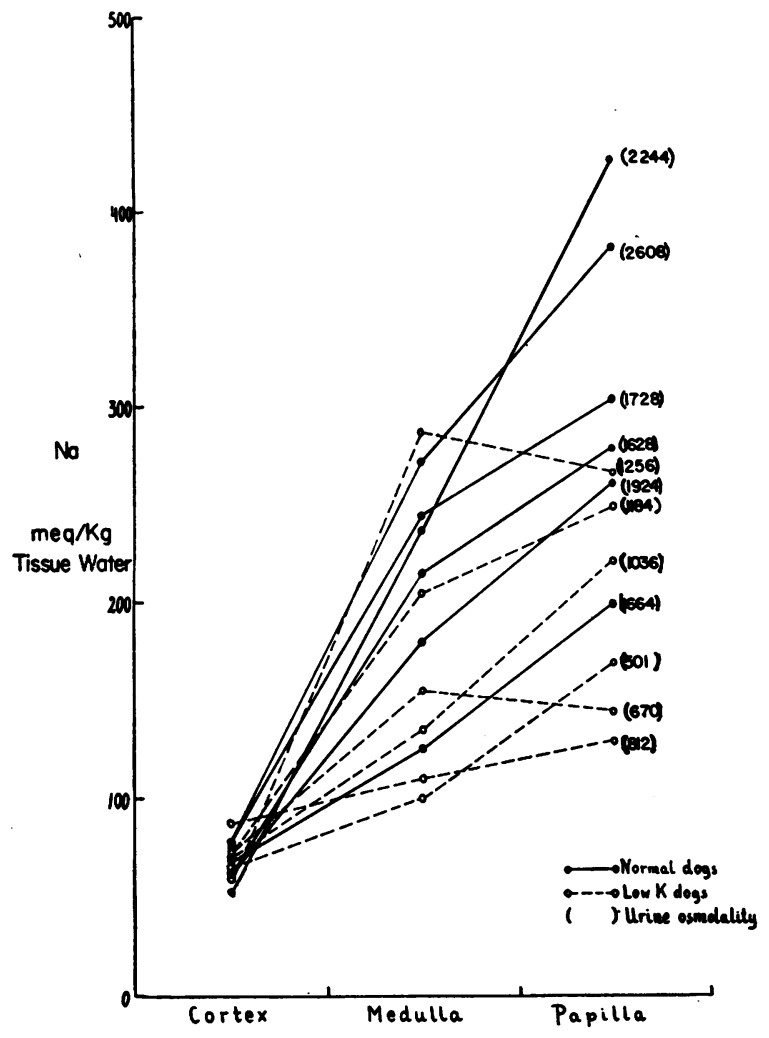

Fig. 3. GRAdient of SOdIUM CONCENTRATION From CORTEX TO MEDULLA IS PLOTTED INDIVIDUALLY FOR NORMAL DOGS (SOLID LINES) AND POTASSIUM-DEPLETED DOGS (BROKEN LINES). The concentration of sodium in the papilla is reduced in potassium-deficient animals, although not so much as is the maximal urinary osmolality (in parentheses).

water, did not reach statistical significance, but in group IIE a significant decrease in the concentration of sodium in tissue water was apparent in both medulla and papilla. An unexpected decrease in the water content of papilla and medulla was apparent in both groups of potassium-deficient rats. "Total solute" concentration of papilla and medulla was significantly diminished by potassium deficiency, as a result of decreases in the concentration of both sodium and urea.

II. Dogs (Tables IV and V). Potassium-depleted dogs became weak, and some (not included here) died with symptoms of paralysis of peripheral and respiratory muscles. Urinary excretion of potassium was extremely low and, as in potassium-depleted rats, difficulty in conserving sodium was noted on a sodium-free diet.

Potassium deficiency was associated with a
TABLE VI

Comparison of urinary osmolality, papillary solute concentration and papillary sodium concentration in normal and potassium-depleted dogs

\begin{tabular}{|c|c|c|c|c|}
\hline & Animal & $U_{o s m}$ & $\begin{array}{l}\text { "Tissue } \\
\text { solutes"* }\end{array}$ & $\begin{array}{c}\text { Papillary } \\
\text { Na }\end{array}$ \\
\hline & no. & $\underset{\mathrm{kg} \mathrm{H} \mathrm{H}_{2} \mathrm{O}}{\mathrm{mOSm} /}$ & $\underset{\mathrm{kg} \mathrm{H} \mathrm{H}_{2} \mathrm{O}}{\text { mmole/ }}$ & $\underset{k g \mathrm{H}}{m E \mathrm{O} /}$ \\
\hline Normal dogs & $\begin{array}{l}75 \\
74 \\
69 \\
73 \\
67 \\
57\end{array}$ & $\begin{array}{l}1,628 \\
1,664 \\
1,728 \\
1,924 \\
2,244 \\
2,608\end{array}$ & $\begin{array}{l}1,448 \\
1,232 \\
1,518 \\
1,339 \\
2,006 \\
2,181\end{array}$ & $\begin{array}{l}279 \\
198 \\
304 \\
262 \\
428 \\
382\end{array}$ \\
\hline
\end{tabular}

Potassiumdepleted dogs

$\begin{array}{rrrr}65 & 501 & 772 & 172 \\ 63 & 670 & 672 & 146 \\ 58 & 812 & 916 & 129 \\ 53 & 1,036 & 1,076 & 222 \\ 70 & 1,184 & 1,174 & 250 \\ 61 & 1,256 & 1,336 & 269\end{array}$

* "Tissue solutes" $=2 \times\left(\mathrm{Na}+\mathrm{K}+\mathrm{NH}_{4}\right)+$ urea.

marked decrease in maximal urinary osmolality and with a significant fall in the concentration of sodium and urea in the renal papilla. (The decrease in water content of medulla and papilla observed in potassium-deficient rats was not noted in dogs.) Figure 3 illustrates the decreased gradient of sodium concentration between cortex, medulla and papilla produced in dogs by potassium depletion.

The calculated solute concentration of the papilla of normal dogs was about 80 per cent of the

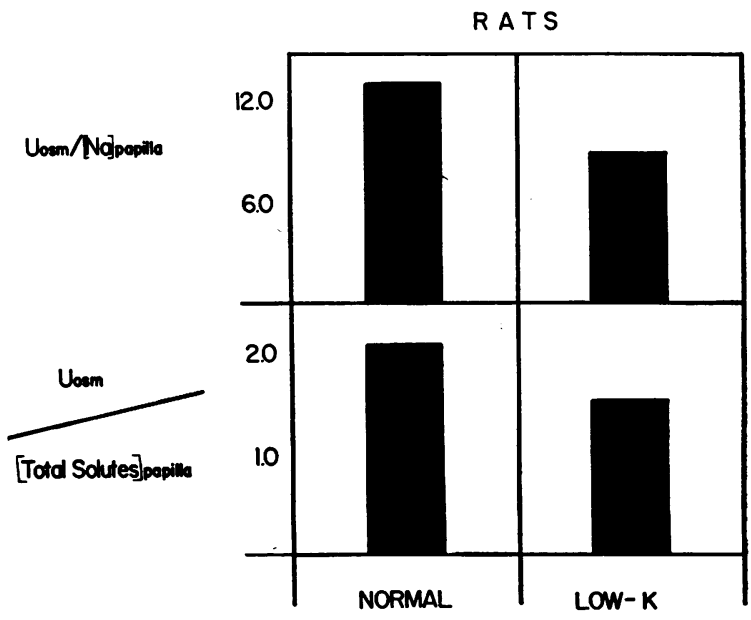

Fig. 4. Potassium depletion produced a deCREASE IN RATIO OF MAXIMAL URINARY OSMOLALITY (UOSM) TO CONCENTRATION (IN MILLIMOLES PER KILOGRAM TISSUE WATER) OF SODIUM AND OF "TOTAL SOLUTES" IN RENAL PAPILla. 
osmolality of urine. In potassium-deficient dogs, on the other hand, total solute concentration of the papilla was equal to or higher than the osmolality of urine (Table VI). These data suggest but do not prove the possibility that the backdiffusion of water from collecting ducts into the interstitium of the papilla may have been impaired by potassium deficiency. Similar alterations were observed in the ratio of urinary osmolality to the concentration of total solutes or sodium in the papilla of potassium-deficient rats (Figure 4), although in the rat experiments urine from several rats was pooled and collected in funnels for 12 hours prior to sacrifice, and the absolute values of such ratios are therefore less meaningful.

\section{DISCUSSION}

These experiments illustrate clearly the effect of potassium depletion in impairing the ability of the kidneys to produce a concentrated urine. Although desoxycorticosterone was used in some rats and dogs to induce potassium deficiency, the results cannot be ascribed to the influence of this hormone, per se, on the renal tubules, since its administration was discontinued many days before the animals were sacrificed. It is unlikely that the low sodium diet to which all animals were subjected substantially affected maximum urinary concentration or the composition of the renal papilla (8).

$A$ priori, the decrease in concentrating ability observed in potassium deficiency might arise from several sources. First, the distal convoluted tubules and collecting ducts might be less permeable to the outward diffusion of water under the influence of vasopressin, so that water would be retained in the urine despite the maintenance of a hypertonic interstitial fluid in medulla and papilla. Giebisch and Lozano concluded that this was an important cause of hyposthenuria in potassiumdepleted dogs, because these animals excreted a hypotonic urine during mild mannitol diuresis despite infusions of vasopressin (9). In the present experiments, the decrease in urinary solute concentration induced by potassium depletion always exceeded the fall in the concentration of sodium or total solutes in the water of the papilla, and presumably, in the papillary interstitium.
These findings are compatible with some impairment of the back-diffusion of water from the collecting ducts, but they do not suffice to establish it.

An increased delivery of hypotonic urine to the distal convolutions and collecting ducts might also play a role in the hyposthenuria of potassium deficiency. It is conceivable, for example, that reabsorption of salt and water in the proximal tubule might be diminished, and that consequently more fluid would be delivered to the ascending limb of Henle's loop, where sodium would be reabsorbed without water. The present data do not bear directly on this possibility, but one might expect that under such circumstances the concentration of sodium in the tissue of the renal medulla would be increased over normal or unchanged, not diminished. It is noteworthy in this connection that the total solute excretion per minute (corrected for body weight) was similar for potassium-depleted animals and for normal controls.

A decrease in the concentration of sodium attained in the interstitial fluids of medulla and papilla would be expected to result in hyposthenuria. The present experiments suggest that this is an important cause of the decrease in renal concentrating ability associated with potassium deficiency. The diminished concentration of sodium in papillary tissue cannot be ascribed to a lower concentration of sodium in the urine of the potassium-depleted animals, since urinary sodium concentration in potassium deficiency was actually higher than that of control animals. Although an increased volume of sodium-poor urine in the collecting ducts of potassium-deficient, polyuric animals might have reduced the papillary concentration of sodium expressed as milliequivalents per kilogram of tissue water, it would not have produced a decrease in the amount of sodium per $100 \mathrm{~g}$ of dry solids.

The decrease in sodium concentration in renal medulla and papilla observed in potassium-deficient animals might result from 1) alterations in countercurrent flow through capillary loops of the vasa recta, 2) impairment of sodium reabsorption from the loops of Henle, or 3) impairment of active reabsorption of sodium without water from the collecting ducts. The data do not 
bear critically on the first possibility, which is difficult to test with present methods. With regard to the second and third alternatives, the tendency of potassium-depleted rats and dogs on a sodium-free diet to lose sodium in the urine suggests impairment of tubular reabsorption of sodium at some site in the nephron. Some sodium transport mechanisms are known to be sensitive to lack of potassium $(10,11)$. The high concentration of sodium normally present in the renal medulla is thought to be a result of active transport of sodium by the loops of Henle (12). Nevertheless, several considerations suggest that in potassium deficiency, impaired reabsorption of sodium from the collecting ducts may be in part responsible for the diminished accumulation of sodium in the papilla. The osmolality of fluid obtained by micropuncture from the early distal convolution of hydropenic potassium-depleted rats is hypotonic to plasma and similar to that of control animals (13). Potassium-deficient rats with impaired concentrating ability are able to dilute the urine normally in response to a water load (14). These facts suggest that in potassium deficiency reabsorption of sodium without water proceeds normally in the loop of Henle. Finally, the alterations in histological structure of the rat kidney produced by potassium depletion are most marked in the collecting ducts (15).

Active reabsorption of sodium from the collecting ducts has been demonstrated by Hilger, Klümper and Ullrich (16). As pointed out by these authors and by Gottschalk and Mylle (12), if during hydropenia the collecting ducts are freely permeable to water, the mere removal of sodium from the urine by collecting duct epithelium might serve to maintain the hypertonicity of medullary interstitial fluid but could not increase it. If, however, sodium reabsorption in this region were linked primarily or partly with the creation of osmotically active particles (for example, the addition to the urine of $\mathrm{NH}_{4}^{+}$) (17), sodium reabsorbed by the collecting ducts could be trapped in the medulla by countercurrent capillary flow (18) and could contribute importantly to the creation of an osmotic gradient between cortex and medulla. It seems reasonable to suppose that the collecting ducts play a role in normal kidneys in establishing this gradient and that this process is disrupted in potassium deficiency.

\section{SUMMARY}

1. The effect of potassium depletion on the composition of renal papilla, medulla and cortex was studied in dogs and rats in an effort to clarify the mechanism of the hyposthenuria produced by potassium deficiency.

2. Potassium deficiency was associated with a fall in the concentration of sodium and urea in the papilla and medulla of hydropenic animals.

3 . The ratio of urinary solute concentration to papillary solute concentration was uniformly lower in potassium-depleted than in normal animals. This finding is compatible with but does not prove the hypothesis that potassium deficiency impairs the permeability of the collecting ducts to water.

4. It is suggested that the defect in renal concentrating ability induced by potassium deficiency may be at least in part a result of impaired reabsorption of sodium by the collecting ducts.

\section{ACKNOWLEDGMENT}

The authors acknowledge gratefully the technical assistance of Mrs. Nadia Myketey and Mrs. Eva Taborsky.

\section{REFERENCES}

1. Relman, A. S., and Schwartz, W. B. The kidney in potassium depletion. Amer. J. Med. 1958, 24, 764.

2. Smith, H. W. The fate of sodium and water in the renal tubules. Bull. N. Y. Acad. Med. 1959, 35, 293.

3. Conway, E. J. Microdiffusion Analysis and Volumetric Error, 4th ed. London, Crosby Lockwood and Son, Ltd., 1957.

4. Maffly, R. H., and Leaf, A. The potential of water in mammalian tissues. J. gen. Physiol. 1959, 42, 1257.

5. Hollander, W., Jr., Winters, R. W., Williams, T. F., Bradley, J., Oliver, J., and Welt, L. G. Defect in the renal tubular reabsorption of waier associated with potassium depletion in rats. Amer. J. Physiol. 1957, 189, 557.

6. Muntwyler, E., and Griffin, G. E. Tissue electrolyte content of potassium and protein-deficient rats. Proc. Soc. exp. Biol. (N. Y.) 1955, 89, 349.

7. Ullrich, K. J., and Jarausch, K. H. Untersuchungen zum Problem der Harnkonzentrierung und Harnverdünnung. Pflüg. Arch. ges. Physiol. 1956, 262, 537. 
8. Manitius, A., Levitin, H., Beck, D., and Epstein, F. H. Unpublished observations.

9. Giebisch, G., and Lozano, R. The effects of adrenal steroids and potassium depletion on the elaboration of an osmotically concentrated urine. J. clin. Invest. $1959,38,843$.

10. Huf, E. G., and Wills, J. Influence of some inorganic cations on active salt and water uptake by isolated frog skin. Amer. J. Physiol. 1951, 167, 255.

11. Ussing, $H$. $H$. Ion transport across biological membranes in Ion Transport across Membranes. New York, Academic Press Inc., 1959.

12. Gottschalk, C. W., and Mylle, M. Micropuncture study of the mammalian urinary concentrating mechanism: Evidence for the countercurrent hypothesis. Amer. J. Physiol. 1959, 196, 927.

13. Gottschalk, C. W., Mylle, M., Winters, R. W., and Welt, L. G. Micropuncture study of the osmolality of renal tubular fluid in potassium-depleted rats (abstract). J. clin. Invest. 1958, 37, 898.
14. Levitin, H., Manitius, A., Beck, D., and Epstein, F. H. Urinary dilution in potassium deficiency. To be published.

15. Oliver, J., MacDowell, M., Welt, L. G., Holliday, M. A., Hollander, W., Jr., Winters, R. W., Williams, T. F., and Segar, W. E. The renal lesions of electrolyte imbalance. I. The structural alterations in potassium-depleted rats. J. exp. Med. 1957, 106, 563.

16. Hilger, H. H., Klümper, J. D., and Ullrich, K. J. Wasserrückresorption und Ionentransport durch die Sammelrohrzellen der Säugetierniere. Pflüg. Arch. ges. Physiol. 1958, 267, 218.

17. Ullrich, K. J., Hilger, H. H., and Klümper, J. D. Sekretion von Ammoniumionen in den Sammelrohren der Säugetierniere. Pflüg. Arch. ges. Physiol. 1958, 267, 244.

18. Berliner, R. W., Levinsky, N. G., Davidson, D. G., and Eden, M. Dilution and concentration of the urine and the action of antidiuretic hormone. Amer. J. Med. 1958, 24, 730. 